\title{
Association between dietary lysine intake and lean body mass among young Indian women
}

Renuka Aggarwal ( $\nabla$ renukaaggarwal@pau.edu )

Punjab Agricultural University https://orcid.org/0000-0002-8646-8792

\section{Kiran Bains}

PAU: Punjab Agricultural University

Harpreet Kaur

Punjab Agricultural University

\section{Research}

Keywords: Protein, lysine, young adult women, fat mass, muscle mass, fat free mass

Posted Date: October 2nd, 2020

DOl: https://doi.org/10.21203/rs.3.rs-84724/v1

License: (c) (i) This work is licensed under a Creative Commons Attribution 4.0 International License. Read Full License 


\section{Abstract}

Background: Lysine is deficient in cereal based traditional Indian diets. Inadequate lysine intakes by Indian population may influence their lean body mass, thereby posing a risk to metabolic diseases and poor fitness. This study investigated associations between intakes of protein and lysine and its existing association with lean mass among Indian women.

Methods: The study was carried out among 473 women. Dietary intake of protein and lysine was estimated via $24 \mathrm{~h}$ recall. Lean body mass based on body composition analysis was assessed. Associations between intakes of protein and lysine with fat mass index, muscle mass index and fat free mass index were analyzed by Pearson's correlation coefficients.

Results: Among women positive and significant associations were found between intake of lysine and muscle mass index $(r=0.221)$ and fat free mass index $(r=0.371)$. An inverse association was found between fat mass index and lysine intake $(r=-0.278)$. Furthermore, the dietary adequacy for protein and lysine was only 71.88 and $39.41 \%$ against the recommended levels.

Conclusions: Diets of the studied population was lacking in lysine. Among women, higher lysine intakes may decrease body fat gain and increase lean body mass suggesting better physical fitness and decreased risk of metabolic diseases.

\section{Background}

Protein quality and quantity is vital to maintain optimum body composition in terms of higher muscle mass which in turn is responsible to keep various metabolic activities in balance for sustainability of healthy human life. Protein intake in the diet directly affects muscle mass as higher amounts of dietary protein leads to greater availability of plasma amino acids resulting in an increased protein synthesis[1]. Protein and amino acids apart from muscle synthesis also play a vital role in bone health, body composition management, satiety, glucose homeostasis, gastrointestinal functions, cell signaling and bacterial flora of the intestine. The larger protein intake than recommendations improve the metabolic function of muscles as more amino acids enhance mitochondrial protein synthesis required for substrate metabolism as well as myofibrillar proteins synthesis[2]. Therefore, a diet should be rich in quality protein which provides all the Indispensible Amino Acids (IAA) required for the metabolic function of the muscles.

Intake of Indispensable amino acids stimulate the synthesis of muscle proteins in the same way as it is stimulated by a combination of IAA and other Dispensable amino acids (DAAs). When a person ingests IAA alone, for the synthesis of new protein, the DAAs that are required by the body can be synthesized efficiently from reutilization of endogenous DAAs. The acute response of protein synthesis and breakdown and dose of ingested IAAs are closely related to each other. During the low dietary doses of IAAs, the stimulation of muscle and synthesis of whole-body protein is linearly related to the increased availability of IAAs. Therefore, a close and linear relationship exists between the amount of IAA in a single meal and between the net gain of body protein[3]. When an increased amount of IAAs are taken at the 
plateau stage, there is a higher synthesis of protein and the protein mass of the body is maintained with an increased rate of protein synthesis and a decreased rate of protein breakdown as compared to the stage when there is lower intake of IAA. An increased rate of muscle protein turnover due to stimulated protein synthesis will improve the muscle quality[4].

Lysine is the first amino acid lacking in cereal-pulse diets and therefore, may affect the protein quality of the diets. Lysine intake in India is low mainly due to lesser food intake, consumption of cereals as staple diet and processing loss of lysine. Furthermore, negligible lysine intakes in low socio-economic group Indians need attention as they are much lower than the daily recommended lysine intake of $45 \mathrm{mg} / \mathrm{g}$ protein for healthy adults[5]. In developing countries like India, where dietary supply of essential amino acids is less, it is pertinent to correctly monitor the relationship between dietary requirements and supply of 'available amino acids' as the deficiency of later is likely to restrict the protein metabolism[6]. In India, cereal-pulse diets and programs providing subsidized foods offer poor quality proteins and raise a risk for quality protein deficiency. It has been found that 4-26\% population of various age groups belonging to rural and urban sectors is at risk of quality protein deficiency[7]. The lower intakes of lysine in Indian population due to demographic, economic, cultural and religious factors may alter their body composition, hence need to be studied considering the importance of lysine and its role in maintaining optimal body composition which in turn, may prove helpful in improving general wellbeing.

\section{Methods}

\section{Sample selection}

A total of 473 young adult women in the age group of 20-30 years residing in PAU, hostels were selected randomly for the study. The studied population was divided in two groups on the basis of their age (Group I: 20-24.9 y and Group II: 25-30 y) so as to find out the effect of age on the observed parameters. Institutional Ethical Committee's approval had been obtained prior to the study. Informed consent was taken from each participant in the study.

\section{Dietary Assessment}

A questionnaire cum interview schedule was used to collect general information and socio-economic profile of the subjects. Information on dietary intake was obtained by a 24-Hour Recall method for 3 consecutive. An interactive, multiple pass, 24-hour recall method was adopted; the interactive approach incorporates several tools to aid participant's memories in recalling details of foods and beverages consumed, including preparation methods and portion sizes. The nutrient intakes were determined using DietCal software[8]. The adequacy of protein was determined by using the recommended dietary allowances (RDA) of Indian Council of Medical Research (ICMR)[9] for women and for lysine, recommendations given by Food and Agricultural Organization[5] were followed.

\section{Body Composition Parameters}


Body composition parameters viz. fat mass, fat free mass, muscle mass, visceral fat, were determined using bioelectrical impedance (TANITA Body composition analyzer BC-420MA). Muscle mass index was calculated from skeletal muscle mass which was derived by using the following equation given by Janssen et al[10]

Skeletal muscle mass $=$

$\left[0.401 *\left(\right.\right.$ height ${ }^{2} /$ bioelectrical impedance $)+\left(3.825^{\star}\right.$ sex $)-(0.071 *$ age $\left.)\right]+5.102$

* with height measured in $\mathrm{cm}$, bioelectrical impedance measured in ohms, sex coded 1 for men and 0 for women, and age measured in years.

Muscle mass index $=$ skeletal muscle mass $/\left(\right.$ height $^{2}$ in $\left.\mathrm{m}\right)$.

and fat mass index was derived from:

$\mathrm{FMI}=$ Fat mass $(\mathrm{kg}) /$ height $(\mathrm{cm})^{2}$

\section{Statistical analysis}

The data was analyzed using SPSS (Statistical Package for the Social Sciences). Mean and standard deviations for various parameters were computed. Student's t-test, analysis of variance (One-way ANOVA) and post hoc test was employed to compare the parameters of the subjects. Pearson's Correlation coefficients $(r)$ were computed to determine the associations between nutrient intake and body parameters.

\section{Results}

An increase in the incidence of metabolic diseases has highlighted the importance of many amino acids especially lysine that has the capacity to alter the body composition offering a protective role for the diseases.

\section{Protein And Lysine Intakes}

The mean total protein intake of Group I (39.22 g) was almost similar to the protein intake of Group II $(40.39 \mathrm{~g})$ as shown in Table 1. The total lysine intake of the subjects in Group II was significantly ( $\mathrm{s}$ 0.05) higher ( $1024.82 \mathrm{mg}$ ) in comparison to Group I $(956.45 \mathrm{mg})$. When the intakes were compared with the recommended dietary allowances, the average protein intake was $71.88 \%$ of the recommended value of $55 \mathrm{~g} /$ day [9] but the mean total lysine intake was only $39.41 \%$ of the recommended levels of $2475 \mathrm{mg} /$ day [5]. On calculating, the lysine intake $(\mathrm{mg})$ in different meals of the day on per gram protein basis, the diets were found to be deficient with an average amount of $24.67 \mathrm{mg}$ lysine on per gram protein basis against the recommended level of $45 \mathrm{mg} / \mathrm{g}$ of protein[5]. 
Table 1

Average daily protein and lysine intake of selected young adult women

\begin{tabular}{|c|c|c|c|c|c|c|}
\hline \multirow[t]{2}{*}{ Meal } & \multicolumn{2}{|l|}{$\begin{array}{l}\text { Group I } \\
(n=346)\end{array}$} & \multicolumn{2}{|l|}{$\begin{array}{l}\text { Group II } \\
(n=127)\end{array}$} & \multicolumn{2}{|l|}{$\begin{array}{l}\text { Overall } \\
(n=473)\end{array}$} \\
\hline & Range & Mean \pm SD & Range & Mean \pm SD & Range & Mean \pm SD \\
\hline \multicolumn{7}{|l|}{ Protein(g) } \\
\hline Breakfast & $\begin{array}{l}1.26- \\
24.69\end{array}$ & $\begin{array}{l}11.31 \\
\pm 4.18^{\mathrm{a}}\end{array}$ & $3.40-19.46$ & $\begin{array}{l}10.68 \\
\pm 3.91^{\mathrm{a}}\end{array}$ & $1.26-24.69$ & $\begin{array}{l}11.14 \\
\pm 4.12\end{array}$ \\
\hline Lunch & $0-29.17$ & $\begin{array}{l}11.57 \\
\pm 4.25^{\mathrm{a}}\end{array}$ & $0-21.88$ & $\begin{array}{l}11.98 \\
\pm 3.79^{\mathrm{a}}\end{array}$ & $0-29.17$ & $\begin{array}{l}11.68 \\
\pm 4.16\end{array}$ \\
\hline Dinner & $\begin{array}{l}1.56- \\
22.48\end{array}$ & $\begin{array}{l}10.12 \\
\pm 3.28^{\mathrm{a}}\end{array}$ & $1.92-20.37$ & $\begin{array}{l}9.88 \\
\pm 3.34^{\mathrm{a}}\end{array}$ & $1.56-22.48$ & $\begin{array}{r}10.06 \\
\pm 3.29\end{array}$ \\
\hline $\begin{array}{l}\text { Mid- } \\
\text { morning }\end{array}$ & $0-8.93$ & $\begin{array}{l}1.48 \\
\pm 1.87^{\mathrm{a}}\end{array}$ & $0-15.68$ & $\begin{array}{l}1.97 \\
\pm 2.64^{\mathrm{b}}\end{array}$ & $0-15.68$ & $\begin{array}{l}1.61 \\
\pm 2.12\end{array}$ \\
\hline $\begin{array}{l}\text { Evening } \\
\text { time }\end{array}$ & $0-18.21$ & $\begin{array}{l}4.74 \\
\pm 3.11^{\mathrm{a}}\end{array}$ & $0-18.87$ & $\begin{array}{l}5.88 \\
\pm 3.57^{\mathrm{b}}\end{array}$ & $0-18.87$ & $\begin{array}{l}5.04 \\
\pm 3.28\end{array}$ \\
\hline Total & $\begin{array}{l}17.91- \\
60.47\end{array}$ & $\begin{array}{l}39.22 \\
\pm 7.73^{\mathrm{a}}\end{array}$ & $20.70-60.38$ & $\begin{array}{l}40.39 \\
\pm 8.46^{\mathrm{a}}\end{array}$ & $\begin{array}{l}17.91- \\
60.47\end{array}$ & $\begin{array}{l}39.53 \\
\pm 7.94\end{array}$ \\
\hline Lysine(mg) & & & & & & \\
\hline Breakfast & $\begin{array}{l}29.84- \\
719.29\end{array}$ & $\begin{array}{l}243.34 \pm \\
131.50^{\mathrm{a}}\end{array}$ & $\begin{array}{l}58.01- \\
551.06\end{array}$ & $\begin{array}{l}243.02 \pm \\
135.79^{a}\end{array}$ & $\begin{array}{l}29.84- \\
719.29\end{array}$ & $\begin{array}{l}243.77 \pm \\
132.19\end{array}$ \\
\hline Lunch & $0-958.97$ & $\begin{array}{l}345.18 \pm \\
148.51^{\mathrm{a}}\end{array}$ & $0-792.62$ & $\begin{array}{l}374.26 \pm \\
153.33^{a}\end{array}$ & $0-958.97$ & $\begin{array}{l}352.99 \pm \\
150.21\end{array}$ \\
\hline Dinner & $\begin{array}{l}17.49- \\
870.38\end{array}$ & $\begin{array}{l}315.60 \\
\pm 144.21^{\mathrm{a}}\end{array}$ & $\begin{array}{l}75.45- \\
738.90\end{array}$ & $\begin{array}{l}308.61 \pm \\
127.94^{\mathrm{a}}\end{array}$ & $\begin{array}{l}17.49- \\
870.38\end{array}$ & $\begin{array}{l}313.72 \pm \\
139.93\end{array}$ \\
\hline $\begin{array}{l}\text { Mid- } \\
\text { morning }\end{array}$ & $0-174.30$ & $\begin{array}{l}7.43 \\
\pm 24.45^{\mathrm{a}}\end{array}$ & $0-772.49$ & $\begin{array}{l}20.21 \\
\pm 98.02^{b}\end{array}$ & $0-772.49$ & $\begin{array}{l}10.86 \pm \\
55.08\end{array}$ \\
\hline
\end{tabular}

Values in columns followed by different superscripts differ significantly $(p \leq 0.05)$ 


\begin{tabular}{|c|c|c|c|c|c|c|}
\hline \multirow[t]{2}{*}{ Meal } & \multicolumn{2}{|l|}{$\begin{array}{l}\text { Group I } \\
(\mathrm{n}=346)\end{array}$} & \multicolumn{2}{|l|}{$\begin{array}{l}\text { Group II } \\
(n=127)\end{array}$} & \multicolumn{2}{|l|}{$\begin{array}{l}\text { Overall } \\
(n=473)\end{array}$} \\
\hline & Range & Mean \pm SD & Range & Mean \pm SD & Range & Mean \pm SD \\
\hline $\begin{array}{l}\text { Evening } \\
\text { time }\end{array}$ & $0-555.12$ & $\begin{array}{l}44.90 \\
\pm 74.72^{\mathrm{a}}\end{array}$ & $0-669.60$ & $\begin{array}{l}78.72 \\
\pm 125.19^{b}\end{array}$ & $0-669.60$ & $\begin{array}{l}53.98 \pm \\
92.14\end{array}$ \\
\hline Total & $\begin{array}{l}308.28- \\
1748.48\end{array}$ & $\begin{array}{l}956.45 \\
\pm 252.51^{a}\end{array}$ & $\begin{array}{l}413.47- \\
2103.00\end{array}$ & $\begin{array}{l}1024.82 \\
\pm 287.01^{b}\end{array}$ & $\begin{array}{l}308.28- \\
2103.00\end{array}$ & $\begin{array}{l}975.32 \\
\pm 263.66\end{array}$ \\
\hline
\end{tabular}


Table 2

Body composition parameters of selected young adult women

\begin{tabular}{|c|c|c|c|c|c|c|}
\hline \multirow[t]{2}{*}{$\begin{array}{l}\text { Body composition } \\
\text { parameters }\end{array}$} & \multicolumn{2}{|c|}{$\begin{array}{l}\text { Group I } \\
(n=346)\end{array}$} & \multicolumn{2}{|l|}{$\begin{array}{l}\text { Group II } \\
(n=127)\end{array}$} & \multicolumn{2}{|l|}{$\begin{array}{l}\text { Overall } \\
(n=473)\end{array}$} \\
\hline & Range & $\begin{array}{l}\text { Mean } \pm \\
\text { SD }\end{array}$ & Range & $\begin{array}{l}\text { Mean } \pm \\
\text { SD }\end{array}$ & Range & $\begin{array}{l}\text { Mean } \pm \\
\text { SD }\end{array}$ \\
\hline Height, cm & $\begin{array}{l}144.50- \\
175.50\end{array}$ & $\begin{array}{l}158.59 \pm \\
5.46^{\mathrm{a}}\end{array}$ & $\begin{array}{l}147.00- \\
169.50\end{array}$ & $\begin{array}{l}157.48 \pm \\
4.81^{b}\end{array}$ & $\begin{array}{l}144.50- \\
175.50\end{array}$ & $\begin{array}{l}158.29 \pm \\
5.31\end{array}$ \\
\hline Weight, Kg & $\begin{array}{l}38.30- \\
56.20\end{array}$ & $\begin{array}{l}58.10 \pm \\
3.63^{\mathrm{a}}\end{array}$ & $\begin{array}{l}41.00- \\
85.10\end{array}$ & $\begin{array}{l}58.79 \pm \\
9.29^{\mathrm{a}}\end{array}$ & $\begin{array}{l}38.30- \\
85.10\end{array}$ & $\begin{array}{l}58.60 \pm \\
4.22\end{array}$ \\
\hline Fat Mass (Kg) & $1.2-40$ & $\begin{array}{l}13.81 \pm \\
6.89^{\mathrm{a}}\end{array}$ & $3-34.1$ & $\begin{array}{l}15.62 \pm \\
6.55^{\mathrm{b}}\end{array}$ & $1.2-40$ & $\begin{array}{l}14.30 \pm \\
6.84\end{array}$ \\
\hline Fat Mass (\%) & $3-45.8$ & $\begin{array}{l}23.70 \pm \\
7.97^{\mathrm{a}}\end{array}$ & $7.2-40.1$ & $\begin{array}{l}25.88 \pm \\
6.80^{\mathrm{b}}\end{array}$ & $3-45.8$ & $\begin{array}{l}24.29 \pm \\
0.73\end{array}$ \\
\hline $\begin{array}{l}\text { Fat Mass Index } \\
\left(\mathrm{Kg} / \mathrm{m}^{2}\right)\end{array}$ & $\begin{array}{l}0.44- \\
17.29\end{array}$ & $\begin{array}{l}5.49 \pm \\
2.72^{\mathrm{a}}\end{array}$ & $\begin{array}{l}1.14- \\
13.49\end{array}$ & $\begin{array}{l}6.28 \pm \\
2.58^{b}\end{array}$ & $\begin{array}{l}0.44- \\
17.29\end{array}$ & $\begin{array}{l}5.70 \pm \\
2.71\end{array}$ \\
\hline Visceral Fat Rating & $1-9$ & $\begin{array}{l}1.72 \pm \\
1.35^{\mathrm{a}}\end{array}$ & $1-7$ & $\begin{array}{l}2.26 \pm \\
1.54^{\mathrm{b}}\end{array}$ & $1-9$ & $\begin{array}{l}1.86 \pm \\
1.42\end{array}$ \\
\hline Muscle Mass (Kg) & $\begin{array}{l}32.4- \\
51.7\end{array}$ & $\begin{array}{l}40.44 \pm \\
4.14^{\mathrm{a}}\end{array}$ & $\begin{array}{l}32.4- \\
52.9\end{array}$ & $\begin{array}{l}39.78 \pm \\
3.29^{\mathrm{a}}\end{array}$ & $\begin{array}{l}32.4- \\
52.9\end{array}$ & $\begin{array}{l}39.96 \pm \\
3.55\end{array}$ \\
\hline Muscle Mass (\%) & $\begin{array}{l}6.74- \\
98.28\end{array}$ & $\begin{array}{l}72.18 \pm \\
10.04^{\mathrm{a}}\end{array}$ & $\begin{array}{l}48.94- \\
95.21\end{array}$ & $\begin{array}{l}70.55 \pm \\
8.21^{\mathrm{a}}\end{array}$ & $\begin{array}{l}6.74- \\
98.28\end{array}$ & $\begin{array}{l}71.74 \pm \\
9.60\end{array}$ \\
\hline $\begin{array}{l}\text { Skeletal Muscle } \\
\text { Mass (Kg) }\end{array}$ & $\begin{array}{l}14.03- \\
94.77\end{array}$ & $\begin{array}{l}21.41 \pm \\
5.20^{\mathrm{a}}\end{array}$ & $\begin{array}{l}13.19- \\
92.56\end{array}$ & $\begin{array}{l}21.06 \pm \\
9.66^{\mathrm{a}}\end{array}$ & $\begin{array}{l}13.19- \\
94.77\end{array}$ & $\begin{array}{l}21.32 \pm \\
7.78\end{array}$ \\
\hline $\begin{array}{l}\text { Muscle mass Index } \\
\left(\mathrm{Kg} / \mathrm{m}^{2}\right)\end{array}$ & $\begin{array}{l}5.74- \\
37.66\end{array}$ & $\begin{array}{l}8.53 \pm \\
10.40^{\mathrm{a}}\end{array}$ & $\begin{array}{l}5.60- \\
37.31\end{array}$ & $\begin{array}{l}8.49 \pm \\
3.87^{a}\end{array}$ & $\begin{array}{l}5.60- \\
37.66\end{array}$ & $\begin{array}{l}8.51 \pm \\
3.17\end{array}$ \\
\hline Fat Free Mass (Kg) & $\begin{array}{l}18.8^{-} \\
54.5\end{array}$ & $\begin{array}{l}42.14 \pm \\
5.20^{\mathrm{a}}\end{array}$ & $\begin{array}{l}18.8- \\
55.7\end{array}$ & $\begin{array}{l}41.74 \pm \\
3.85^{\mathrm{a}}\end{array}$ & $\begin{array}{l}18.8^{-} \\
55.7\end{array}$ & $\begin{array}{l}41.85 \pm \\
4.25\end{array}$ \\
\hline Fat Free Mass (\%) & $\begin{array}{l}7.09- \\
97.43\end{array}$ & $\begin{array}{l}75.72 \pm \\
10.94^{\mathrm{a}}\end{array}$ & $\begin{array}{l}30.17- \\
96.37\end{array}$ & $\begin{array}{l}73.58 \pm \\
10.25^{a}\end{array}$ & $\begin{array}{l}7.09- \\
97.43\end{array}$ & $\begin{array}{l}75.17 \pm \\
10.78\end{array}$ \\
\hline $\begin{array}{l}\text { Fat Free Mass Index } \\
\left(\mathrm{Kg} / \mathrm{m}^{2}\right)\end{array}$ & $\begin{array}{l}8.03- \\
21.34\end{array}$ & $\begin{array}{l}17.01 \pm \\
2.08^{\mathrm{a}}\end{array}$ & $\begin{array}{l}7.03- \\
22.39\end{array}$ & $\begin{array}{l}16.62 \pm \\
1.60^{\mathrm{a}}\end{array}$ & $\begin{array}{l}7.03- \\
22.39\end{array}$ & $\begin{array}{l}16.73 \pm \\
1.75\end{array}$ \\
\hline
\end{tabular}

Values in columns followed by different superscripts differ significantly $(p \leq 0.05)$ 
The average percent body fat mass of the subjects in Group I and II was 23.70 and $25.88 \%$, respectively. A significantly $(p \leq 0.05)$ higher fat mass was observed among the subjects in Group II in comparison to Group I. The mean fat mass index values of the subjects in Group I and Group II was 5.49 and $6.28 \mathrm{~kg} / \mathrm{m}^{2}$, respectively, the values of group I were close to the cut off value of 5.5 but the subjects in Group II had average fat mass index above this cut-off [11]. A significantly $(p \leq 0.05)$ lower fat mass index of the subjects in Group I was observed when compared to Group II. Moreover, the excess body fat was found among 50 and $60 \%$ of the subjects in Group I and II, respectively (Fig. 1). A significant ( $\mathrm{p} \leq$ $0.05)$ increase in visceral fat rating of the subjects was observed with the advancement of age. The total muscle mass and skeletal muscle mass of the subjects in Group I was 40.44 and $21.41 \mathrm{~kg}$, respectively, the corresponding values for the subjects in Group II were 39.78 and $21.06 \mathrm{~kg}$. On the other hand, the average values of fat free mass in both the groups were 42.14 and $41.74 \mathrm{~kg}$, the percent fat free mass being 75.72 and $73.58 \%$, respectively. The fat free mass index of the subjects in Group I and II was 17.01 and 16.62 whereas, the muscle mass index calculated from skeletal muscle mass values was 8.53 and 8.49 for Group I and II, respectively. Thirty and $17 \%$ of the subjects had muscle mass index and fat free mass index lesser than the respective cut off values of 15.4[11] and 7.6[12] hence, possessed lesser muscle mass as depicted in Figs. 2 and 3.

\section{Associations Between Lysine Intakes And Body Composition}

The statistical analysis using Pearson's Correlation Coefficient (Table 3) showed that protein intake of the subjects was negatively and significantly $(p \leq 0.05,0.01)$ correlated with the parameters of general obesity (BMI) and abdominal obesity (Waist circumference). Further, higher intake of protein was positively and significantly $(p \leq 0.05,0.01)$ correlated with muscle mass percent, muscle mass index and fat free mass index, hence, associated with enhanced muscle mass. Similarly, higher lysine intakes were associated with lower obesity as lysine intake was found to be negatively and significantly $(p \leq 0.05$, 0.01) correlated with body weight, body mass index, waist circumference, waist and hip ratio and fat mass index. Lysine intake was also found to be positively and significantly $(p \leq 0.05,0.01)$ correlated with percent muscle mass, muscle mass index and fat free mass index thereby, proved that lysine inadequacy is associated with poor muscle mass. 
Table 3

Correlation Coefficients ( $r$ ) among nutrients, anthropometry and body composition parameters

\begin{tabular}{|c|c|c|}
\hline Parameter & Protein & Lysine \\
\hline Body weight & - & $-0.135^{\star}$ \\
\hline Body Mass Index & $0.325^{\star \star}$ & -0.231 ** \\
\hline Waist Circumference & $0.152^{\star}$ & -0.251 ** \\
\hline Waist and Hip Ratio & - & $-0.154^{\star}$ \\
\hline Fat Mass Index & - & -0.278 ** \\
\hline Muscle Mass\% & $0.318^{\star \star}$ & $0.314 \star \star$ \\
\hline Muscle mass Index & $0.210^{\star *}$ & $0.221^{\star \star}$ \\
\hline Fat free mass Index & $0.382^{*}$ & $0.371^{\star}$ \\
\hline${ }^{*} \mathrm{p} \leq 0.05 ; * * \mathrm{p} \leq 0.01$ & & \\
\hline
\end{tabular}

\section{Discussion}

The dietary adequacy of protein was $71.88 \%$ among the young Punjabi adult women in the present study. Another study from Punjab reported the daily protein intake ranged between $21.0-58.0 \mathrm{~g} /$ day with the mean value of $37.7 \mathrm{~g} /$ day and the mean adequacy being $69.6 \%$ among 21-30 y old women[13]. The adequate protein quantity in diet is vital for muscle synthesis, the ingestion of approximately $25-30 \mathrm{~g}$ of protein per meal maximally stimulates muscle protein synthesis in both young and older individuals, however, muscle protein synthesis is blunted when the quantity of protein is less than approximately $20 \mathrm{~g}$ per meal[14]. If compared to the reported study, the subjects from both the age groups showed inadequate intake of protein $(1.48-11.98 \mathrm{~g})$ in all the meals which may affect the muscle protein synthesis and body composition. Further, the subjects who all were consuming traditional diets were not able to have adequate lysine from their regular meals as average lysine adequacy was as low as $39.41 \%$ which is quite serious nutritional issue for cereal based Indian diets. A study suggested that the rate of synthesis of all classes of muscle proteins are acutely regulated by the blood indispensable amino acids (IAA) and proposed that the stimulation of protein synthesis depends on the sensing of the concentration of extracellular, rather than intramuscular IAAs[2]. So, it is important that the IAAs in every meal should be sufficient for their proper utilization for muscle protein synthesis.

The average body fat among the studied population was $24.29 \%$. A study reported the body fat of Indian women $(21-30 \mathrm{y})$ in the range of $13.9-40.6 \%$ with a mean value of $25.0 \%$ [15] while another study observed the body fat of Caucasian adult women in the range of 11.6 to $53.7 \%$ with a mean value of 
$28.7 \%[11]$. Fat mass index is considered as a better predictor of generalized obesity compared to body mass index and percent body fat[16]. Fat mass Index (FMI) and Fat Free Mass Index (FFMI) can recognize whether the excess or deficit of body weight is due to the change of fat mass (FM) or fat free mass (FFM) or both and can provide information about actual body composition that may better reflect nutrition status[11]. The fat mass index higher than the cut off value was found in 53 percent of the subjects. The fat mass index of Caucasian adult women ranged between $5.5-9.3 \mathrm{~kg} / \mathrm{m}^{2}$ has been reported[11], but was found to be on an average of $6.0 \mathrm{~kg} / \mathrm{m}^{2}$ among 20-30 y old Punjabi women. The young women in the present study had an average muscle mass of $39.96 \mathrm{~kg}$. A muscle mass at 95th percentile as $40.50 \mathrm{~kg}$ among 20-30 years old women has been reported[17]. Greater muscle mass in older adults is associated with lower all-cause mortality and total mortality was significantly lower in the fourth quartile of muscle mass index compared to the first[12]. The fat free mass index of the subjects was higher than the cut off value of 15.4. An optimum fat free mass among $93 \%$ of Punjabi women in age group of 21 to $30 \mathrm{y}$ has been reported[15].

The foregoing results showed that the fat related body composition parameters were higher among the subjects in older age group (Group II) indicating that age is an important determinant of body fat. The literature reports that muscles play a significant role in obesity and the muscles in the body can be increased with a diet high in protein content with good amount of essential amino acids especially lysine[18]. The protein intake directly affects muscle mass as higher amounts of dietary protein leads to greater availability of plasma amino acids resulting in an increased protein synthesis leading to more of muscle mass while a decrease in body fat, fat mass and anthropometric parameters like waist and waist circumference[1]. In the present study, inadequate protein and lysine intakes were found to be negatively correlated with the parameters of general obesity (BMI) and abdominal obesity (Waist circumference). The positive and significant $(p \leq 0.05,0.01)$ correlation of these nutrients with percent muscle mass, muscle mass index and fat free mass index proved that protein and lysine inadequacy is associated with poor muscle mass. Diets rich in protein and specially lysine promote muscle mass[19]. A study reported that fat mass and fat free mass play a significant role in determination of energy intake by an individual. Fat mass is positively related to hunger and energy intake while fat free mass shows a weak negative or no association with it. However, higher energy intake resulting in positive energy balance will always lead to an increase in BMI, waist circumference and WHR[20].

\section{Conclusions}

As the results indicated increase of fat related body composition parameters with the advancement of age and role of protein and lysine intake for improved body composition, it is important to control the changes in these parameters at the early age. If this change is controlled in the younger age with the higher intake of essential amino acids like lysine then it may improve the body composition of women in the form of proportionally more fat free mass and lesser fat mass, which in turn, may prove helpful in improving general well-being, physical fitness as well as preventing metabolic diseases. Therefore, the present study shows that cereal based traditional Indian diets are inadequate in protein and lysine and 
has negative effect on fat free mass. These diets may satisfy hunger and provide sufficient energy, but fails to provide the required quantities of nutrients affecting their body composition. In light of the results obtained, there is a need to shift the objectives of various policies and programs providing subsidized foods from energy sufficiency to a more nutrient quality sufficiency, of which high quality protein should be an integral part.

\section{Declarations}

Ethical approval and consent to participate: All procedures used in this study involving research study participants were approved by the Institutional ethical Committee of Punjab Agricultural University, Ludhiana . A prior written consent of the subjects to participate in the study was obtained.

Consent for publication: Written consent for publication was obtained from all the subjects involved in the study.

Availability of data and materials: The datasets used and/or analysed during the current study are available from the corresponding author on reasonable request.

Competing interests: The authors declare that they have no competing interests.

Funding : Not Applicable

Authors' contributions : First Author: Formulating and designing the study, carrying it out, analysing the data and writing the manuscript.

Second Author: Formulating and designing the study, writing the manuscript

Third author: Collection and Analyzing the data

Acknowledgements: Not Applicable

\section{References}

1. Motil KJ, Matthews DE, Bier DM, Burke JF, Munro HN, Young VR. Whole-body leucine and lysine metabolism: response to dietary protein intake in young men. Am J Physiol Endocrinol Metab.1981; 240: 712-21.

2. Bohe J, Low A, Wolfe RR and Rennie MJ. Human muscle protein synthesis is modulated by extracellular but not intracellular amino acid availability: a dose response study. J Physiol.2003; 552: 315-24.

3. Wolfe RR, Shane RM, Kim Y,Moughan PJ.Protein quality as determined by the Digestible Indispensable Amino Acid Score: evaluation of factors underlying the calculation. Nut Rev.2016;74: 584-99. 
4. Fitts RH, Ramatowski JG, Peters JR. The deleterious effects of bed rest on human skeletal muscle fibers are exacerbated by hypercortisolemia and ameliorated by dietary supplementation. Am J Physiol Cell Physiol.2007;293: 313-20.

5. Dietary Protein Quality evaluation in human nutrition. Report of an FAO expert consultation. Food and Nutrition paper. 2013; 92.

6. Rowan AM, Moughan PJ, Wilson MN, Maher K, Tasman JC.Comparison of the ileal and faecal digestibility of dietary amino acids in adult humans and evaluation of the pig as a model animal for digestion studies in man. Br J Nutr.1994;71: 29-42.

7. Minocha S, Thomas T, Kurpad AV. Dietary protein and the health-nutrition-agriculture connection in India. J Nutr.2017; 147: 1243-50.

8. Kaur G. Diet Cal- $A$ tool for dietary assessment and planning. All India Institute of Medical Sciences, New Delhi.2014.

9. Indian Council of Medical Research. Nutrient requirements and recommended dietary allowances for Indians. National Institute of Nutrition, Hyderabad; 2010.

10. Janssen I, Heymsfield SB, Baumgartner RN, Ross R.Estimation of skeletal muscle mass by bioelectrical impedance analysis. J Appl Physiol.2000;89: 465-71.

11. Schutz Y, Kyle UU, Pichard C. Fat -free mass index and fat mass index percentils in Caucasians aged 18-98 y. Int J Obes.2002; 26: 953-60.

12. Srikanthan $P$ and Karlamangla AS. Muscle Mass Index as a Predictor of Longevity in Older-Adults. Am J Med.2014; 127: 547-53.

13. Kaur $\mathrm{G}$ and Bains K. Effect of protein quality and quantity on body composition of sedentary adult women. Ind J Nutr Dietet, 2013; 50: 15-23.

14. Paddon-Jones $D$ and Rasmussen BB. Dietary protein recommendations and the prevention of sarcopenia. Curr Opinion Clin Nutr Meta Care.2009; 12: 86-90.

15. Kaur G, Bains K, Kaur H, Kaur A. Assessment of changes in anthropometry and body composition with progression of age among occupationally sedentary women. Int J Health Nutr.2012; 3: 13-18.

16. Singhal N, Mathur P,Pathak R.Validity of simple, novel measures of generalized and central obesity among young Asian Indian women. Indian J Med Sci.2011;65: 518-27.

17. Marwaha RK, Garg MK, Bhadra K, Mithal A,Tandon N.Assessment of lean (muscle) mass and its distribution by dual energy X-ray absorptiometry in healthy Indian female. Arch Osteoporos.2014; 9: 186.

18. Paddon JD, Sheffield MM, Zhang XJ, Volpi E, Wolf SE, Aarsland A, Ferrando AA, Wolfe RR. Amino acid ingestion improves muscle protein synthesis in the young and elderly. Am J Physiol Endocrinol Metab.2004; 286: 321-28.

19. Civitelli R, Villareal D T, Agnusdei D, Nardi P, Avioli LV,Gennari Dietary L-lysine and calcium metabolism in humans. Nutrients.1992; 8: 400-05. 
20. Stubbs RJ, Hopkins M, Finlayson GS, Duarte C, Gibbons C, Blundell JE. Potential effects of fat mass and fat-free mass on energy intake in different states of energy balance. Euro J Clin Nutr.2018; 72 : 698-09.

\section{Figures}

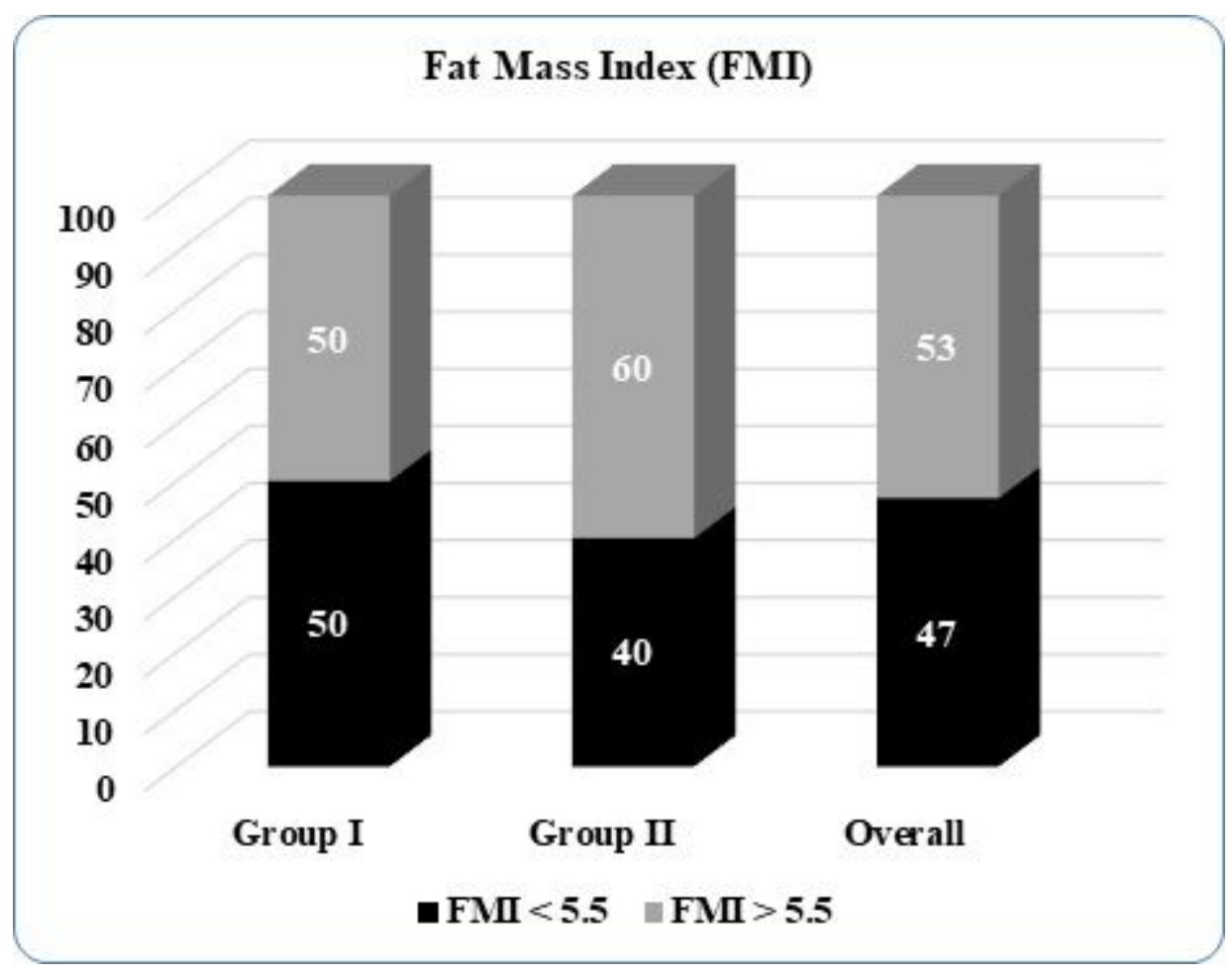

Figure 1

Categorization of the selected young women on the basis of Fat Mass Index[11]

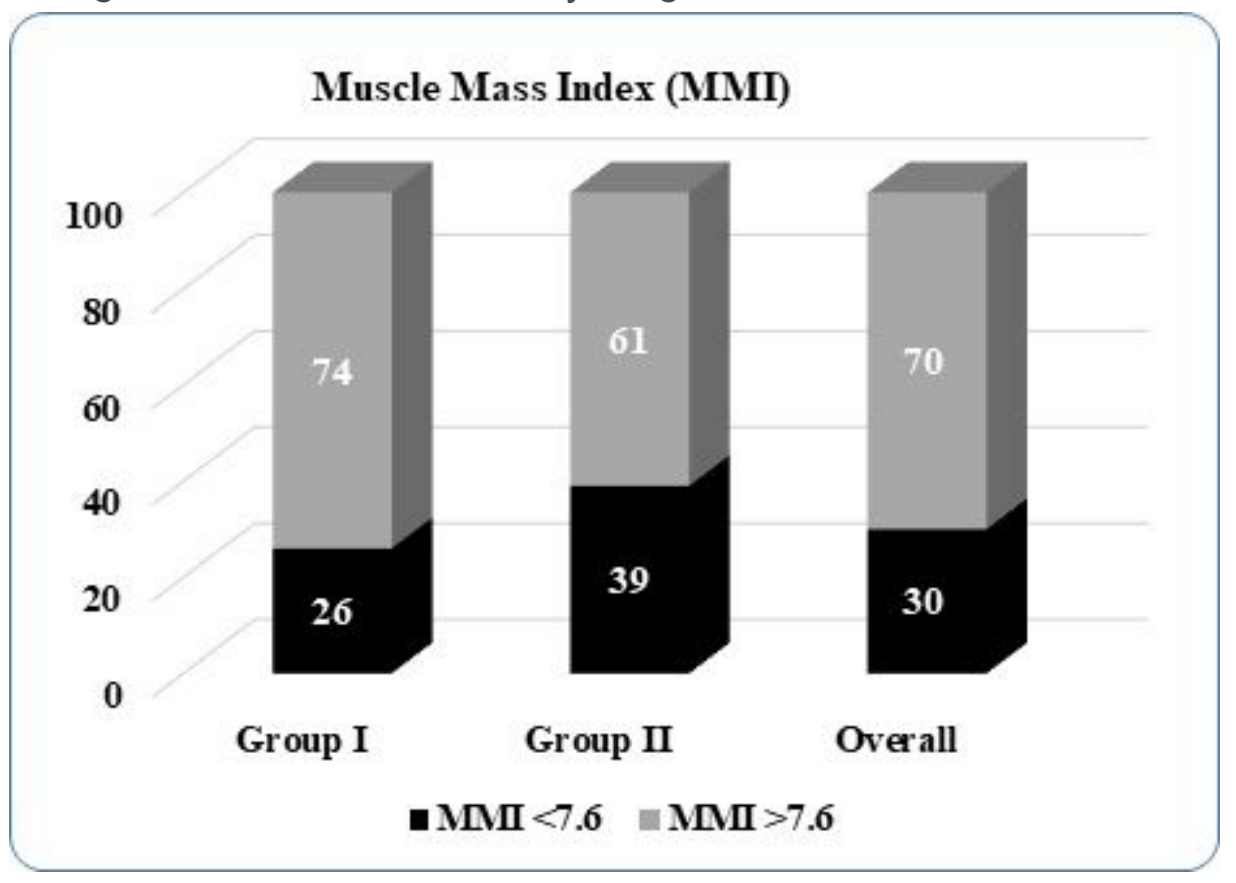


Figure 2

Categorization of the selected young women on the basis of Muscle Mass Index[12]

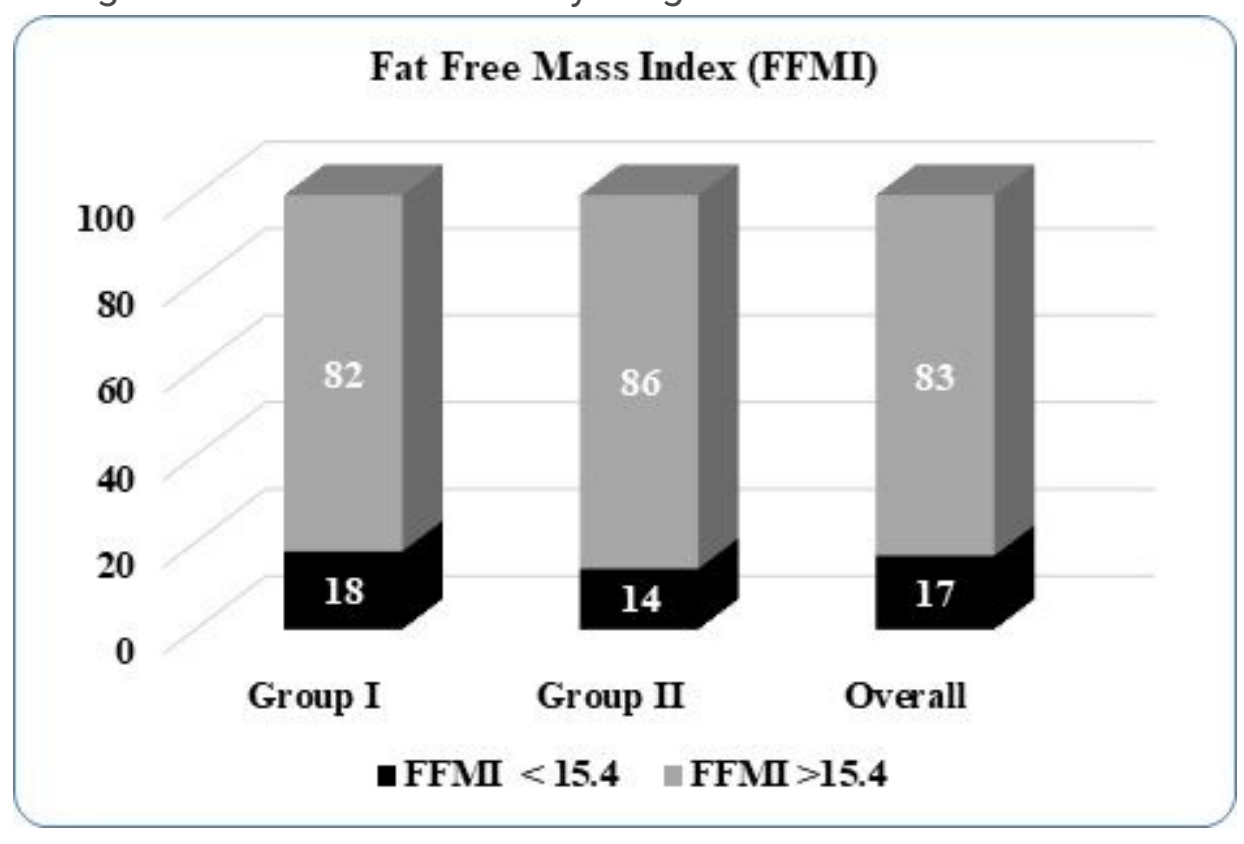

Figure 3

Categorization of the selected young women on the basis of Fat Free Mass Index[11] 